\title{
PLIOCENE MOLLUSCS TAXONOMIC DIVERSITY AS A TOOL FOR THE CLIMATIC-OCEANOGRAPHIC RECONSTRUCTION AND STRATIGRAPHY. TWO EXAMPLES FROM THE EASTERN MEDITERRANEAN*
}

\author{
E. Koskeridou' \\ ${ }^{1}$ National and Kapodistrian University of Athens, Faculty of Geology and Geoenvironment, \\ Department of Historical Geology - Paleontology, \\ ekosker@geol.uoa.gr
}

\begin{abstract}
Due to their high extinction rate, the Molluscs of the Pliocene in the Mediterranean, resulted potentiaily useful as a tool for climatic-oceanographic and chronological inferences.

In the present study, we document the possibility of application of the model of Raffi and Monegatti (1993) in the region of Eastern Mediterranean, by studying two examples from the Hellenic area and Cyprus.

This model concerns the extinction events of Molluscs of Pliocene, separating 4 different units of Molluscs with different climatic-oceanographic importance. It is documented that the two selected sections, Atsipades in central Crete and Athienou in southern Cyprus, give elements for the correlation of their deposits with this model. The Atsipades section is connected with the first significant extinction event, at the Mollusc Units of Raffi and Monegatti, resulting from the first important Pliocene cooling phenomenon of our hemisphere. The Athienou section is connected with the MPMU2 unit of Raffi and Monegatti, between the first and second distinctive extinction events of the Pliocene Molluscs.

Key words: bivalvia, ecobiostratigraphy, Mediterranean, Pliocene, taxonomic diversity.
\end{abstract}

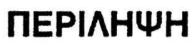

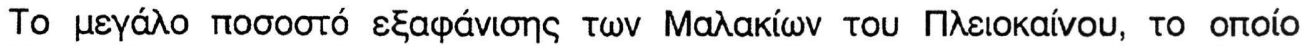

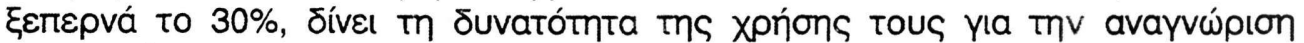

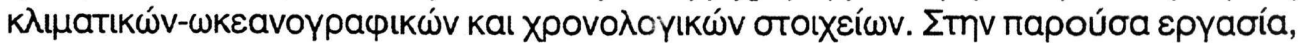

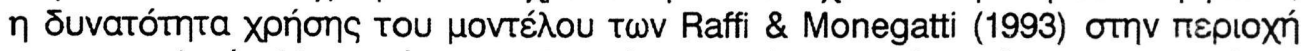

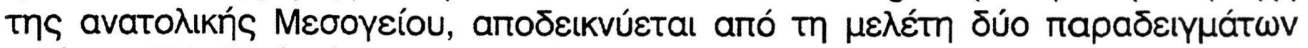

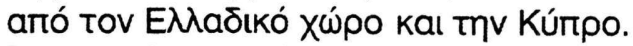

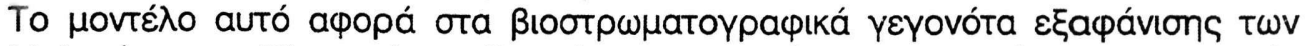

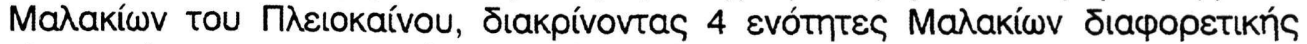

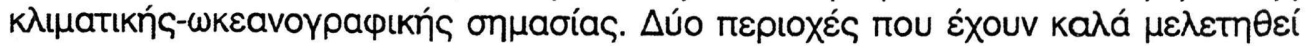

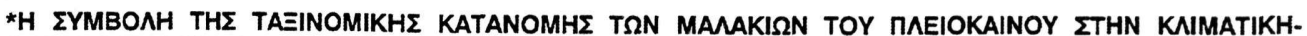

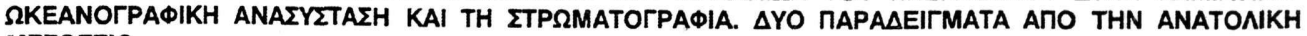
MEEOTEIO

E. Кобкврі́боu

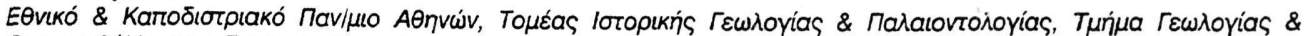

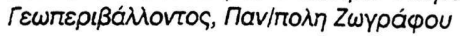




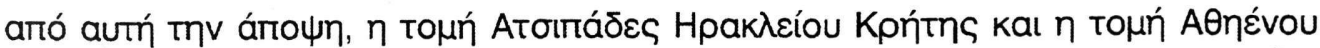

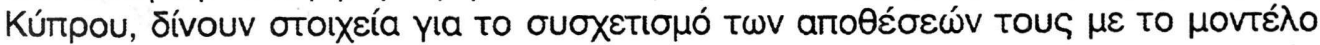

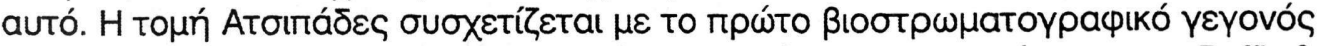

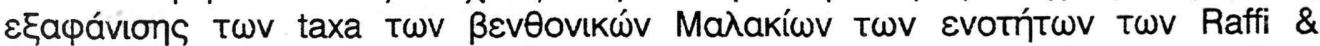

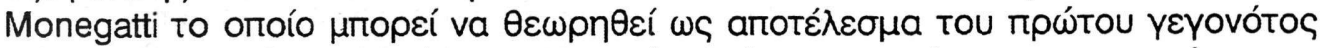

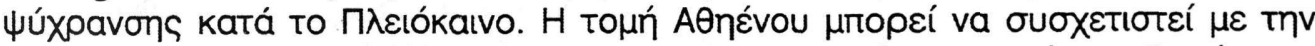

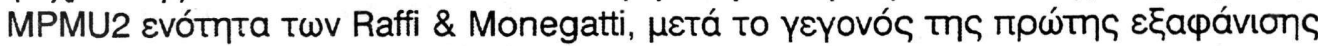

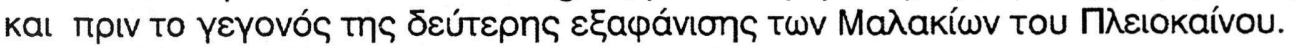

\section{Introduction}

The reduction in taxonomic diversity of marine Molluscs throughout the Pliocene in the Mediterranean, has been reported already by Levi (1900) (in Ruggieri, 1962). Up to the 50's it was believed that the Pliocene faunas were stable and were represented by warm-water taxa, which they were disappeared in the uppermost Piacenzian or at the P/P boundary. In the 60's (Ruggieri, $1962,1967)$, it was clarified that Pliocene is characterized by the progressive reduction of Molluscs taxonomic diversity, due to progressive climatic cooling. Raffi and Monegatti (1993) and Monegatti and Raffi (2001) took into their consideration the elements of the extinction events for the Pliocene of Italy, distinguishing 4 different Pliocene Molluscan Units (MPMU) (Fig. 1), of different climatic-oceanographic importance. They recognized that the knowledge of the statigraphic range of Molluscs calibrated by biostratigraphic and magneto-biostratigraphic data could well play an important role in the stratigraphic classification of sections that characterize shallow water environments, when the calcareous plankton

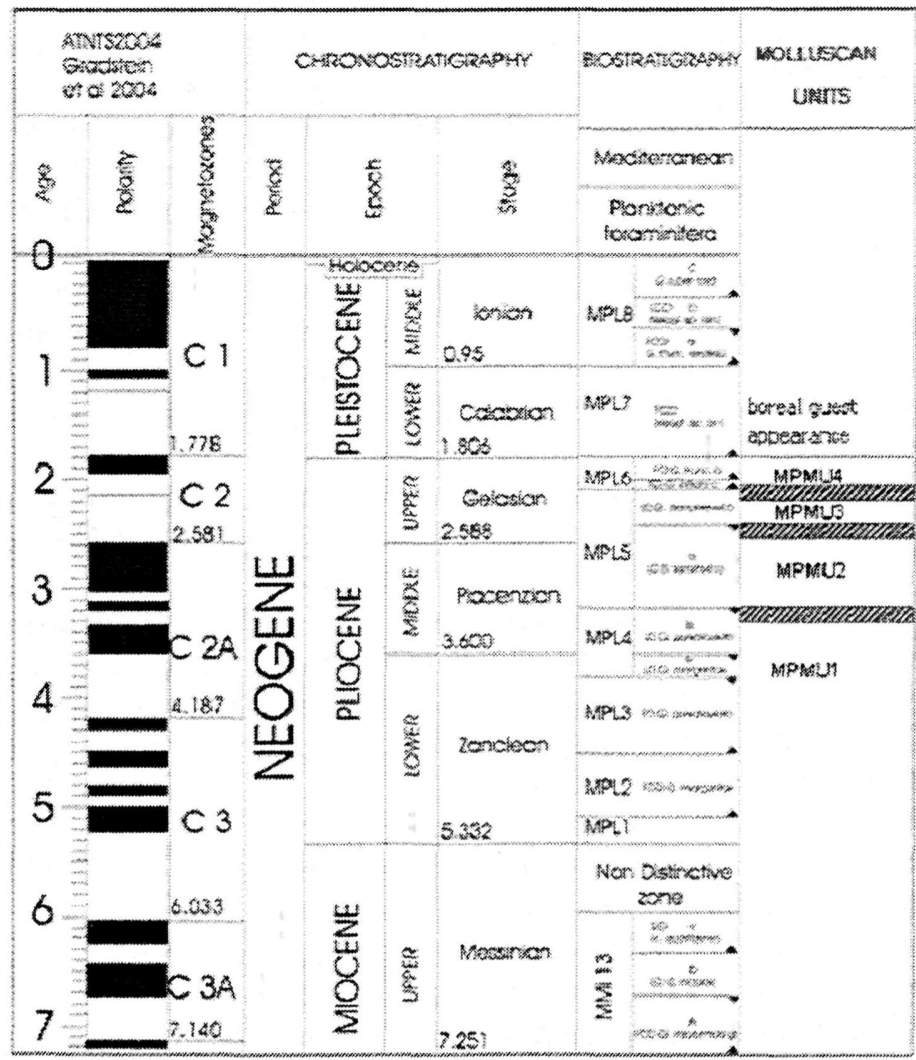

Fig. 1. Mediterranean Pliocene Molluscan units (MPMU) correlated to the Planctonic foraminifera biostratigraphy, to the Standard Global Chronostratigraphic Scale and to Geomagnetic Polarity Time Scale (Gradstein et al., 2004). 
is absent.

For the Greek Neogene, an extended investigation of the faunal succession has been worked out (Dermitzakis \& Georgiades-Dikeoulia, 1987).

This research has allowed a first approach to the analysis of the molluscan taxonomic diversity and a proposed biozonation which corresponds to 4 assemblage biozones and one acme zone for the Pliocene. These data gave the possibility of working out a chronological framework for the Greek Pliocene, based on marine molluscs and in particularly on the bivalves.

In this work, we make an effort to investigate whether the extinction events during the Pliocene (according to Raffi \& Monegatti, 1993) can be recognized and give more precise chronological data in the Eastern Mediterranean too.

\section{Discussion}

As three major extinction phases have been evidenced during the Pliocene in the Mediterranean basin, by means of Molluscan fauna, four MPMU were recognized by Raffi and Monegatti (1993). As these extinction events were not followed by recovery phases, a progressive decrease in warm-water taxa occurred. Every MPMU was defined by the lack of taxa which disappeared in the immediately previous extinction event and by the presence of the particular taxa which disappears in the successive extinction phase.

In order to study the applicability of Raffi and Monegatti model, the control of systematic classification of the Mediterranean Pliocene Molluscs, is essential. For Italy, this work has been almost completed with the study of 356 species of infralittoral and circalittoral environments. Dermitzakis \& Georgiades-Dikeoulia (1987), contrib- ute significantly to this field, for the Greek area. Nevertheless it is necessary to extend this study on the Hellenic area and on the Eastern Mediterranean.

For this purpose, a multi-disciplinary approach has to be carried out, including biostratigraphic, magnetostratigraphic and paleoecological data.

On this frame, we attempted to correlate two representative sections (Atsipades in central Crete and Athienou in south Cyprus), by means of Molluscs systematic classification, biostratigraphy and paleoenvironmental characteristics with the Mollucsc Units of Raffi and Monegatti.

Further objective documentation based on the study of more Pliocene outcrops of eastern Mediterranean is necessary.

\subsection{Study area}

The Atsipades section, is located in Central Crete, in the southern part of the Hiraklion Basin (sensu Meulenkamp et al., 1994). It is approximately $80 \mathrm{~m}$ thick, representing a shallowing upward sequence from outer shelf marls and sandy marls at the bottom, to shallow inner shelf deposits at the top of the section (Fig. 2).

The biostratigraphical analysis based on planktonic foraminifera and nannofossils, determined the base of the succession as younger than $3.61 \mathrm{Ma}$ and the top up to $3.21 \mathrm{Ma}$.

The fossil assemplages of the greater area, have been recorded by (Symeo-

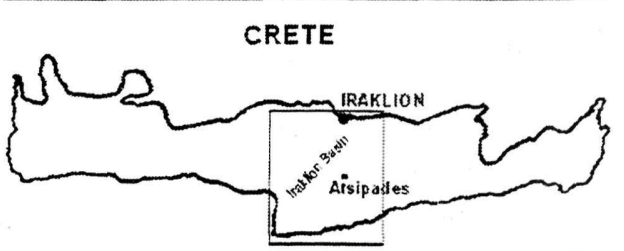

Fig. 2. Schematic map of Crete indicating the location of the study area 
nidis and Konstantinidis, 1967, Zachariasse, 1975, Dermitzakis and Georgiades-Dikeoulia, 1983, Koskeridou, 1997, Koskeridou et al., 2002).

The paleoecological analysis based on foraminifera and molluscs, show that to the bottom of the section the environmental conditions was more typical of deeper waters with high productivity and moderate oxygen content (Drinia et al., 2005). The deposits of the middle and upper part of the sequence, thought, are being characteristics of normal salinity and high oxygenation environment of the inner shelf. Therefore, rich macrobenthic assemblages, including Bivalves, Gastropods, Brachiopods, Echinoids and Annelids, colonized these settlements (Koskeridou et al. 2002).

As for the MPMU, Raffi and Monegatti, did not use species typical of bathyal biofacies, the correlation with our sections, have been done only in the parts that correspond in shallower-water zones.

The second section studied, was Athienou, which is situated near Athienou (South Cyprus) (Fig. 3), at the southeastern opening of the Mesaoria basin to the open sea. At the end of Pliocene the Mesaoria basin became a narrow shallow sandy platform (Mc Callum and Robertson, 1990). The Athienou section belongs to Nicosia Formation and it has been studied by Koskeridou et al. (2005). In terms of biostratigraphy, the section belongs to the Globorotalia crassaformis Zone (Spaak, 1983) and has a Middle Pliocene age as has been proved by the cooccurrence of the planktonic foraminifera species Globorotalia crassaformis and

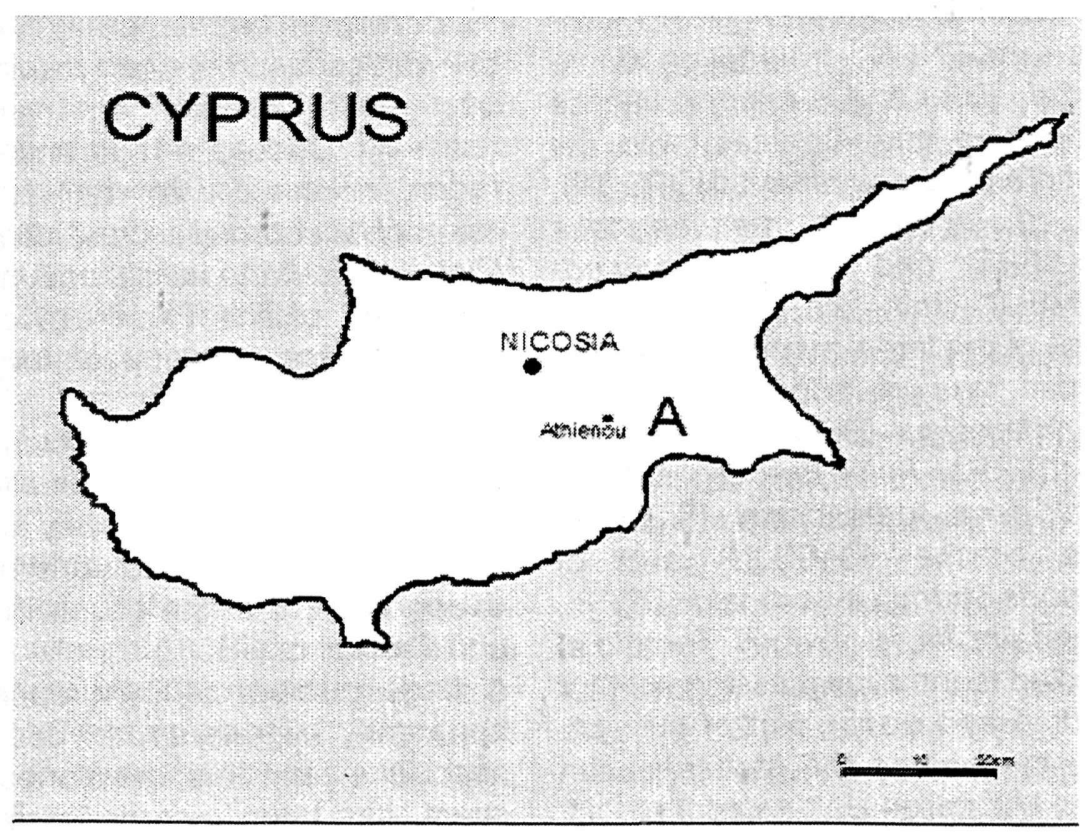

Fig. 3. Schematic map of Cyprus indicating the location (A) of the study area 
Globorotalia bononiensis. The studied invertebrate faunal component points to very good ecological conditions of normal salinity and high oxygenation and indicates an environment $130 \mathrm{~m}$ in depth.

\section{Results}

The fauna from Atsipades section indicating the neritic zone, shows an interesting similarity with this of the first appreciable extinction event (immigration and local disappearance) of tropical Mollusc taxa, as these have been determined by Raffi et al. (1989) in the Mediterranean Pliocene, which approximates or just follows the first occurrence of Globorotalia bononiensis and G. crassaformis.

These beds are remarkable for their relatively abundant, well-preserved macrofossils, mostly bivalves and gastropods (Koskeridou et al., 2002). The presence of Flabellipecten flabelliformis (BR.), Chlamys scabrella (LK.), Dymia fragilis (KOENEN), Neopycnodonte navicularis (BR.) and a minor presence of Terebridae and Conidae, with the species Terebra acuminata (BORSON), Conus (Lautoconus) mediterraneus BRUGUIERE and Conus ventricosus GMELIN, has been noticed. The absence of the large number of benthic molluscan taxa of tropical affinity as Chlamys latissima (BROCCHI), Callista italica (DEFR.), Pelecyora gigas (LK.), Pseudoxyperas proaspersa (SACCO), Tugona anatina (GMELIN) and of Gastropods Strombus coronatus DEFR., Ficus and Ancilla, is obvious. Therefore, the studied fauna allows assignment for the middle and upper part of the section, to the limit of the Mediterranean Pliocene Molluscan Unit 1 and 2 of Raffi \& Monegatti (1993).

The deposits of Athienou section, also contain a rich Mollusc and Brachiopod fauna. The most dominant representatives of the Gastropods and Bivalves are: Neopycnodonte navicularis (Brocchi), Glossus humanus (L.), Chlamys opercularis (L.), Chlamys angelonii (Meneghini), Chlamys glabra L., Amussium cristatum (Bronn), Pecten jacobaeus (L.) and Chlamys flexuosa Poli. The total composition of the fauna along with the lack of tropical taxa, the minor appearance of Terebridae and Conidae and the presence of Neopycnodonte navicularis, allow the emplacement of these deposits between the first and the second extinction event in the Mediterranean Pliocene, and the assignment to the MPMU2 of Raffi and Monegatti (1993), which is in accordance with the biostratigraphical interpretation by the planktonic Foraminifera.

The composition of the Mollusc fauna of the two studied sections should be considered the effect of the first incident of falling temperatures during the Pliocene. The first cooling wave occurred in the Northern hemisphere relatively sudden, in high and mid latitudes, in accord with the first appearance of Globorotalia crassaformis and Globorotalia bononiensis and marks the beginning of the Plio-Pleistocene ice age, with the absence of fully developed ice sheets yet.

However the presence of thermophilic benthic Molluscs, in the studied sections, suggests that relatively high temperatures (higher than today's) occurred during that era, in the coasts of Cyprus and Crete.

A large number of thermophilic taxa apparently migrate south, due to that specific event. This mentioned above event, has been recorder also, in the coasts of North Atlantic and was a small scale global event. 


\section{Conclusions}

The faunal assemblages of two studied sections, Atsipades (Central Crete) and Athienou (South Cyprus) suggest that there is possible applicability of the Raffi \& Monegatti (1993) model, to the Eastern Mediterranean.

There are similarities between the contained fauna in these two sections and the Mollusc fauna diversity patterns which lead to the MPMU zones of the previous mentioned authors.

The deposits of Atsipades and Athienou sections are well calibrated by biostratigraphical data. The environmental factors -except the temperature- that fauna indicates in these two sections, seems to be favourable for tropical taxa, which are in this case lacking. Also a drastic decrease in other taxa of Bivalves and Gastropods is occurred. These elements lead to the conclusion that the Molluscs fauna of these deposits are connected with the first significant extinction event, at the Mollusc Units of Raffi and Monegatti, resulting from the first important Pliocene cooling phenomenon of our hemisphere.

In order that these observations should be effect in Eastern: Mediterranean, detailed studies should be carried out in other regions of this area. The results of this work constitute spark on studies to the direction of determination of Molluscs extinction patterns of Eastern Mediterranean.

\section{References}

Dermitzakis, M.D., and E., GeorgiadesDikeoulia, 1987. Biozonation of the Neogene invertebrate megafauna of the Hellenic area. Ann. Inst. Geol. Publ. Hungarici, (Procced.), Vol. LXX, p.125-135.

Drinia, H., Koskeridou, E., and Antonarakou, A., 2005. Late Pliocene Benthic
Foraminifera and Molluscs from the Atsipades Section, Central Crete; Paleoecological Distribution and use in Paleoenvironmental Assessment. Geobios 38, 315-324.

Koskeridou, E., Antonarakou, A., Drinia, H., and Triantaphyllou, M.V., 2002. Paleoecological observations on the Upper Pliocene deposits of Atsipades Section (C. Crete). Proceedings, $6^{\text {th }}$ Panhellenic geographical conference of the Hellenic Geographical Society, vol. I: 123-130.

Koskeridou, E., Vardala-Theodorou, G.E., Tsiolakis, E., Panayides, I., Theodorou, G., and Antonarakou, A., 2005. The marine faunistic assemblages of the Pliocene of Paleometocho and Athienou (Cyprus, East Mediterranean): some palaeoecological aspects. Abstracts, 12th RCMNS Congress, Vienna 2005, p. 134-136.

Meulenkamp, J.E., Van Der Zwaan, G.J., Van Wamel, W.A., 1994. On late Miocene to Recent vertical motions in the Cretan segment of the Hellenic arc. Tectonophysics, 234, 53-72.

Monegatti, P., and Raffi, S., 2001. Taxonomic diversity and stratigraphic distribution of Mediterranean Pliocene bivalves. Palaeogeography, Palaeoclimatology, Palaeoecology, 165, I. 3-4, 171-193.

Raffi, S., and Monegatti, P., 1993. Bivalve taxonomic diversity throughout the Italian Pliocene as a tool for climatic-oceanographic and stratigraphic inferences. Proc. 1st RCANS Congr., Lisbon, 1992. -Ciencias della Terra, $12: 45-50$.

Ruggieri, G., 1950. Contribuzione alla conoscenza della malacofauna e della stratigrafia del Pliocene e del Quaternario. Giorn. Di Geol. 21 : 65-90. 
Ruggieri, G., 1962. La serie marina pliocenica e quaternaria della Romana. A cura della Camera de Com. Ind. E Agric. De Forli, 1-76.

Ruggieri, G., 1967. The Miocene and later evolution of the Mediterranean Sea, in Adams \& Ager, D.V., Aspects of Tethyan Biogeography, Syst. Assoc. Publ. 7: 283-290.
Symeonidis, N., Konstantinidis, D., 1967. Observations on the Neogenic formations of Central Crete, Annales Geologiques des Pays Helleniques, 19, 657-688.

Zachariasse, W.J., 1975. Planktonic foraminiferal biostratigraphy of the Late Neogene of Crete. Utrecht Micropaleontological Bulletin, 11, 171pp. 